\title{
Erratum to: Simple fluorescence assay for quantification of OSCS in heparin
}

\author{
Susanne Lühn • Simone Schiemann • Susanne Alban
}

Published online: 31 October 2010

(C) Springer-Verlag 2010

Erratum to: Anal Bioanal Chem

DOI 10.1007/s00216-010-3867-5

Regrettably, there was an error in the concentration of heparinase I.

The concentration of heparinase I should correctly read $\mathrm{mIU} \mathrm{mL}^{-1}$ instead of IU $\mu \mathrm{L}^{-1}$. 